\title{
THE AMINO ACID SEQUENCE OF AMPHOMYCIN
}

\section{THE “CORE-HEXAPEPTIDE”}

\author{
Miklos Bodanszky, Agnes A. Bodanszky, \\ Carol A. Ralofsky, Robert G. Strong, \\ Department of Chemistry, Case Western Reserve University, \\ Cleveland, Ohio 44106, U. S. A. \\ and Rodger L. Foltz \\ Columbus Laboratories of Battelle Memorial Institute, \\ Columbus, Ohio 43201, U. S. A.
}

(Received for publication February 17, 1971)

\begin{abstract}
A hexapeptide with the amino acid sequence glycyl-D-erythro- $\alpha, \beta$-diaminobutyryl-L-valyl-L-prolyl-(L-threo- $\alpha, \beta$-diaminobutyric acid, D-pipecolic acid) was obtained by selective acid hydrolysis of amphomycin.
\end{abstract}

Selective hydrolysis of amphomycin with boiling $0.03 \mathrm{~N}$ hydrochloric acid ${ }^{1)}$ resulted in the liberation of the fatty acid residues ${ }^{2)}$ which acylate the N-terminal moiety*. Three moles of $\mathrm{L}$-aspartic acid $^{3)}$, one mole of $\mathrm{L}$-threo- $\beta$-methylaspartic acid ${ }^{4)}$ and one mole of glycine were also found to be present in the mixture. From the method of cleavage $^{1)}$, it is obvious that the glycine originates from a residue between two aspartyl moieties (or one aspartyl and the $\beta$-methylaspartyl residue) in the sequence of the antibiotic. The remaining constituents ${ }^{3)}$, one mole each of glycine, L-proline, L-valine, D-pipecolic acid, L-threo- $\alpha, \beta$-diaminobutyric acid, and D-erythro- $\alpha, \beta$-diaminobutyric acid ${ }^{5}$, were found in a hexapeptide which could be purified by ionexchange chromatography or by preparative paper chromatography and was isolated in larger amounts by countercurrent distribution. From the conditions of the hydrolysis, it can be deduced that in the sequence of the parent molecule, the hexapeptide is both preceded and followed by aspartic acid (or $\beta$-methylaspartic acid). Therefore, this fragment is the central part of the amphomycin molecule and will be called the "core-hexapeptide" in this paper**.

From its amino acid composition, it seemed highly probable that the corehexapeptide of amphomycin is identical with one of the fragments obtained by FUJINO $^{6)}$ in the partial acid hydrolysis of glumamycin. To exclude the remote possibility that the two antibiotics, amphomycin and glumamycin, have identical amino acid compositions but with the residues arranged in different sequences, a more detailed study of the hexapeptide was necessary. Furthermore, in the structural studies on

\footnotetext{
* Hydrolysis with boiling $0.25 \mathrm{~N}$ acetic acid for 1 hour also cleaves amphomycin. An ether-extractable material, L-aspartic acid acylated by fatty acids, was isolated from the hydrolysate. This is the N-terminal part of the antibiotic.

** Under identical conditions, the same fragment is liberated from aspartocin (cf. ref. 8).
} 
glumamycin ${ }^{7)}$, the two $\alpha, \beta$-diaminobutyric acid constituents were considered to have the same stereochemistry. This conclusion seems to be erroneous: if for no other reasons, because of racemization during hydrolysis ${ }^{5)}$ the presence of two diastereoisomers must be postulated in the hydrolysis mixture, even if only one of these would participate as a constituent in the parent molecule. Our studies ${ }^{5)}$ demonstrated that, in amphomycin, one of the $\alpha, \beta$-diaminobutyric acid residues has the $\mathrm{D}$-erythro ( ${ }^{\mathrm{D}} \mathrm{Dab}$ ), the other the L-threo configuration $\left({ }^{\mathrm{t}} \mathrm{Dab}\right)$. The lack of differentiation between the isomers rendered the otherwise elegant work ${ }^{6)}$ on glumamycin incomplete and necessitated a new effort toward the sequence of the core-hexapeptide. The results of these investigations add support to our contention ${ }^{8)}$ that glumamycin and amphomycin are identical.

The $\mathrm{N}$-terminal residue of the core-hexapeptide was shown, both by dansylation ${ }^{9)}$ and by EDMAN degradation ${ }^{10)}$, to be glycine. It was less easy to assign a sequence to the other five amino acids. No method was found for a selective cleavage of the hexapeptide, and the presence of the two $\alpha, \beta$-diaminobutyric acid residues further complicated the determination of sequence: e.g., the EDMAN method, af ter one cycle, failed to give useful information. An attempt was made to elucidate the sequence through identification of the diketopiperazines (DKPs) formed in the pyrolysis of the hexapeptide. The presence of the DKP -Val-Pro- could be firmly established by the characteristic mass spectrum, especially with chemical ionization. The second major component, the DKP of pipecolic acid (Pip) and dehydrobutyrine (Dhb) obviously originates from the DKP -Pip-Dab-l. The next-neighbor relationship (Pro, Val) and (Dab, Pip) were insufficient for the assignment of a sequence even when considered together with the earlier found ${ }^{11}$ next-neighbor relationship ( ${ }^{\mathrm{D}} \mathrm{Dab}, \mathrm{Val}$ )* and with the knowledge that glycine is the $\mathrm{N}$-terminal. Therefore, a reexamination of the

Table 1. High-resolution mass spectrometric data of the "core-hexapeptide" a)

\begin{tabular}{|c|c|c|c|c|}
\hline Mass found & Int. $(\%)$ & Mass calcd. & Elemental comp. & Interpretation \\
\hline 438.238 & 0.7 & 438.235 & $\mathrm{C}_{20} \mathrm{H}_{32} \mathrm{~N}_{5} \mathrm{O}_{6}$ & Ac(Gly, Ac-Dab, Val, Pro) \\
\hline 410.248 & 0.4 & 410.240 & $\mathrm{C}_{19} \mathrm{H}_{32} \mathrm{~N}_{5} \mathrm{O}_{5}$ & $-\mathrm{CO}$ \\
\hline 379.197 & 0.3 & 379.198 & $\mathrm{C}_{18} \mathrm{H}_{27} \mathrm{~N}_{4} \mathrm{O}_{5}$ & -acetamide \\
\hline 322.182 & 0.6 & 322.177 & $\mathrm{C}_{16} \mathrm{H}_{24} \mathrm{~N}_{3} \mathrm{O}_{4}$ & -acetylglycinamide \\
\hline 341.185 & 7.0 & 341.183 & $\mathrm{C}_{15} \mathrm{H}_{25} \mathrm{~N}_{4} \mathrm{O}_{5}$ & Ac(Gly, Ac-Dab, Val) \\
\hline 313.187 & 2.7 & 313. 188 & $\mathrm{C}_{14} \mathrm{H}_{25} \mathrm{~N}_{4} \mathrm{O}_{4}$ & $-\mathrm{CO}$ \\
\hline 282.149 & 4.1 & 282.145 & $\mathrm{C}_{13} \mathrm{H}_{20} \mathrm{~N}_{3} \mathrm{O}_{4}$ & -acetamide \\
\hline 225.123 & 2.7 & 225.124 & $\mathrm{C}_{11} \mathrm{H}_{17} \mathrm{~N}_{2} \mathrm{O}_{3}$ & -acetylglycinamide \\
\hline 242.114 & 11.0 & 242.114 & $\mathrm{C}_{10} \mathrm{H}_{16} \mathrm{~N}_{3} \mathrm{O}_{4}$ & $A c(G l y, A c-D a b)$ \\
\hline 214.118 & 4.4 & 214. 119 & $\mathrm{C}_{9} \mathrm{H}_{16} \mathrm{~N}_{3} \mathrm{O}_{3}$ & $-\mathrm{CO}$ \\
\hline 183.077 & 2.3 & 183. 077 & $\mathrm{C}_{8} \mathrm{H}_{11} \mathrm{~N}_{2} \mathrm{O}_{3}$ & -acetamide \\
\hline 126.054 & 0.5 & 126.055 & $\mathrm{C}_{6} \mathrm{H}_{8} \mathrm{NO}_{2}$ & - acetylglycinamide \\
\hline 100.040 & 3.1 & 100.040 & $\mathrm{C}_{4} \mathrm{H}_{6} \mathrm{NO}_{2}$ & Ac-Gly \\
\hline 72.045 & 20.6 & 72.045 & $\mathrm{C}_{3} \mathrm{H}_{6} \mathrm{NO}$ & $-\mathrm{CO}$ \\
\hline 194.105 & 100 & 194.105 & $\mathrm{C}_{10} \mathrm{H}_{14} \mathrm{~N}_{2} \mathrm{O}_{2}$ & -Pip-Dhb- \\
\hline
\end{tabular}

a) After acetylation and treatment with diazomethane.

* The tentative squence ${ }^{11}$ ) of valine and $\mathrm{D}$-erythro- $\alpha, \beta$-diaminobutyric acid had to be revised. The formation of several products through rearrangements during the slow hydrolysis ${ }^{11)}$ made this assignment difficult. 
sequence with the aid of high-resolution mass spectra (HRMS) was decided upon.

The core-peptide was acetylated with acetic anhydride in acetic acid and the product treated, in methanol, with an ethereal solution of diazomethane. Data of the HRMS are listed in Table 1. The observed masses gave sufficient evidence on the order (Gly-Dab-Val-Pro-) of the first four amino acids in the sequence of the core-hexapeptide, but not enough information was obtained about the C-terminal part, most of which appeared in the form of -Dhb-Pip(mass 194). Because of the remaining ambiguity, the HRMS of an acetylatedpermethylated $^{12,13)} \quad$ sample were also examined. The pertinent data of this spectrum are summarized in Table 2. Finally, a sample of the acetyl-hexapeptide was permethylated with $\mathrm{CD}_{3} \mathrm{I}^{14,15)}$. The HRMS (Table 3) was particularly clear. Nevertheless, the spectra obtained on permethylated samples merely confirmed the sequence of the first four residues in the corehexapeptide. The conclusions from the HRMS study are summarized in sequence I. as $\mathrm{Dhb} \cdot \mathrm{OCH}_{3}$.
Table 2. High-resolution mass spectrometric data. Acetylated-permethylated "core-hexapeptide"

\begin{tabular}{|c|c|c|c|c|}
\hline $\begin{array}{l}\text { Mass } \\
\text { found }\end{array}$ & $\begin{array}{l}\text { Int. } \\
(\%)\end{array}$ & $\begin{array}{l}\text { Mass } \\
\text { calcd. }\end{array}$ & $\begin{array}{c}\text { Elemental } \\
\text { Comp. }\end{array}$ & Interpretation a) \\
\hline 508.317 & 3.3 & 508.314 & $\mathrm{C}_{25} \mathrm{H}_{42} \mathrm{~N}_{5} \mathrm{O}_{6}$ & Ac. $\left(\right.$ Ala $\left.^{b}\right)$, Ac-Dab, Val, Pro) \\
\hline 494.298 & 17.9 & 494.298 & $\mathrm{C}_{24} \mathrm{H}_{40} \mathrm{~N}_{5} \mathrm{O}_{6}$ & Ac. (Gly, Ac-Dab, Val, Pro) \\
\hline 466.299 & 1.8 & 466.302 & $\mathrm{C}_{23} \mathrm{H}_{40} \mathrm{~N}_{5} \mathrm{O}_{5}$ & $-\mathrm{CO}$ \\
\hline 435.261 & 0.5 & 435.261 & $\mathrm{C}_{22} \mathrm{H}_{35} \mathrm{~N}_{4} \mathrm{O}_{5}$ & Ac. (Alab), Dhb, Val, Pro) \\
\hline 421.253 & 0.8 & 421.245 & $\mathrm{C}_{21} \mathrm{H}_{33} \mathrm{~N}_{4} \mathrm{O}_{5}$ & Ac. (Gly, Dhb, Val, Pro) \\
\hline 350.209 & 8.6 & 350.208 & $\mathrm{C}_{18} \mathrm{H}_{28} \mathrm{~N}_{3} \mathrm{O}_{4}$ & Ac. (Dhb, Val, Pro) $\left.{ }^{c}\right)$ \\
\hline 411.262 & 1.5 & 411.261 & $\mathrm{C}_{20} \mathrm{H}_{35} \mathrm{~N}_{4} \mathrm{O}_{5}$ & Ac. $\left.\left(\mathrm{Ala}^{\mathrm{b}}\right), \mathrm{Ac}-\mathrm{Dab}, \mathrm{Val}\right)$ \\
\hline 397.246 & 14.6 & 397.245 & $\mathrm{C}_{19} \mathrm{H}_{33} \mathrm{~N}_{4} \mathrm{O}_{5}$ & Ac. (Gly, Ac-Dab, Val) \\
\hline 369.245 & 1.2 & 369.250 & $\mathrm{C}_{18} \mathrm{H}_{33} \mathrm{~N}_{4} \mathrm{O}_{4}$ & $-\mathrm{CO}$ \\
\hline 324.193 & 10.3 & 324.192 & $\mathrm{C}_{16} \mathrm{H}_{26} \mathrm{~N}_{3} \mathrm{O}_{4}$ & Ac. (Gly, Dhb, Val) \\
\hline 310.179 & 1.1 & 310.177 & $\mathrm{C}_{15} \mathrm{H}_{24} \mathrm{~N}_{3} \mathrm{O}_{4}$ & Ac. $\left(\mathrm{Gly}, \mathrm{Dhb}, \mathrm{Val} \mathrm{l}^{\mathrm{d}}\right)$ \\
\hline 253.155 & 59.3 & 253.155 & $\mathrm{C}_{13} \mathrm{H}_{21} \mathrm{~N}_{2} \mathrm{O}_{3}$ & Ac. $(\mathrm{Dhb}, \mathrm{Val})$ \\
\hline 298. 177 & 3. 0 & 298.177 & $\mathrm{C}_{14} \mathrm{H}_{24} \mathrm{~N}_{3} \mathrm{O}_{4}$ & Ac. $(\text { Alab) }, A c-D a b)^{e)}$ \\
\hline 284.165 & 12.3 & 284.161 & $\mathrm{C}_{13} \mathrm{H}_{22} \mathrm{~N}_{3} \mathrm{O}_{4}$ & Ac. (Gly, Ac-Dab) \\
\hline 256.165 & 1.4 & 256.166 & $\mathrm{C}_{12} \mathrm{H}_{22} \mathrm{~N}_{3} \mathrm{O}_{3}$ & 11 \\
\hline 225.125 & 3.5 & 225.124 & $\mathrm{C}_{11} \mathrm{H}_{17} \mathrm{~N}_{2} \mathrm{O}_{3}$ & Ac. $\left(A l a^{b)}, D h b\right)^{f)}$ \\
\hline 211.107 & 6.8 & 211.108 & $\mathrm{C}_{10} \mathrm{H}_{15} \mathrm{~N}_{2} \mathrm{O}_{3}$ & Ac. (Gly, Dhb) \\
\hline 183.113 & 7.5 & 183.113 & $\mathrm{C}_{9} \mathrm{H}_{15} \mathrm{~N}_{2} \mathrm{O}_{2}$ & $-\mathrm{CO}$ \\
\hline 140.073 & 44.9 & 140.071 & $\mathrm{C}_{7} \mathrm{H}_{10} \mathrm{NO}_{2}$ & $\mathrm{Ac}-\mathrm{Dhb}$ \\
\hline 128.071 & 16. 2 & 128.071 & $\mathrm{C}_{6} \mathrm{H}_{10} \mathrm{NO}_{2}$ & $\mathrm{Ac}-\mathrm{Ala}{ }^{\mathrm{b}, \mathrm{g})}$ \\
\hline 114.055 & 100.0 & 114.055 & $\mathrm{C}_{5} \mathrm{H}_{8} \mathrm{NO}_{2}$ & Ac-Gly \\
\hline 100.076 & 17.2 & 100.076 & $\mathrm{C}_{5} \mathrm{H}_{10} \mathrm{NO}$ & $\mathrm{Ac}-\mathrm{Ala}-\mathrm{CO}$ \\
\hline 86.060 & 12.4 & 86.061 & $\mathrm{C}_{4} \mathrm{H}_{8} \mathrm{NO}$ & Ac-Gly-CO \\
\hline 208. 119 & 2.14 & 208.121 & $\mathrm{C}_{11} \mathrm{H}_{16} \mathrm{~N}_{2} \mathrm{O}_{2}$ & -Dhb-Pip \\
\hline
\end{tabular}

a) With the exception of Pro and Pip, all the residues are considered N-methylated; b) From C-methylation of Gly ; c) 494-acetylsarcosine methylamide; d) Val, not permethylated; e) Could be (Pro, Ac-Dab). $\mathrm{OCH}_{3}$; f) Corresponds also to $(\mathrm{Pro}, \mathrm{Dhb}) \cdot \mathrm{OCH}_{3} ; \mathrm{g}$ ) Could be interpeted

Table 3. High-resolution mass spectrometric data. Acetylated-perdeuteriomethylated "core-hexapeptide"

\begin{tabular}{|c|c|c|c|c|}
\hline $\begin{array}{l}\text { Mass } \\
\text { found }\end{array}$ & $\begin{array}{l}\text { Int. } \\
(\%)\end{array}$ & $\begin{array}{l}\text { Mass } \\
\text { calcd. }\end{array}$ & $\begin{array}{l}\text { Elemental } \\
\text { comp. }\end{array}$ & Interpretation* \\
\hline 506.375 & 2.7 & 506.373 & $\mathrm{C}_{24} \mathrm{H}_{28} \mathrm{D}_{12} \mathrm{~N}_{5} \mathrm{O}_{6}$ & Ac(Gly, Dab, Val, Pro) \\
\hline 409. 321 & 5.2 & 409. 320 & $\mathrm{C}_{19} \mathrm{H}_{21} \mathrm{D}_{12} \mathrm{~N}_{4} \mathrm{O}_{5}$ & Ac(Gly, Dab, Val) \\
\hline 333. 252 & 18.4 & 333.249 & $\mathrm{C}_{16} \mathrm{H}_{17} \mathrm{D}_{9} \mathrm{~N}_{3} \mathrm{O}_{4}$ & Ac(Gly, Dhb, Val) \\
\hline 293. 221 & 7.2 & 293.217 & $\mathrm{C}_{13} \mathrm{H}_{13} \mathrm{D}_{9} \mathrm{~N}_{3} \mathrm{O}_{4}$ & Ac(Gly, Dab) \\
\hline 217.146 & 18.1 & 217.146 & $\mathrm{C}_{10} \mathrm{H}_{9} \mathrm{D}_{6} \mathrm{~N}_{2} \mathrm{O}_{3}$ & Ac (Gly, Dhb) \\
\hline 189. 155 & 8.3 & 189. 151 & $\mathrm{C}_{9} \mathrm{H}_{9} \mathrm{D}_{6} \mathrm{~N}_{2} \mathrm{O}_{2}$ & $-\mathrm{CO}$ \\
\hline 143.089 & 8.7 & 143.090 & $\mathrm{C}_{7} \mathrm{H}_{7} \mathrm{D}_{3} \mathrm{NO}_{2}$ & Ac-Dhb \\
\hline 131.085 & 5.2 & 131.090 & $\mathrm{C}_{6} \mathrm{H}_{7} \mathrm{D}_{3} \mathrm{NO}_{2}$ & Ac-Ala ** \\
\hline 117.074 & 61.1 & 117.074 & $\mathrm{C}_{5} \mathrm{H}_{5} \mathrm{D}_{3} \mathrm{NO}_{2}$ & Ac-Gly \\
\hline 103. 095 & 31.0 & 103. 095 & $\mathrm{C}_{5} \mathrm{H}_{7} \mathrm{D}_{3} \mathrm{NO}$ & $\mathrm{Ac}-\mathrm{Ala}-\mathrm{CO}$ \\
\hline 89.080 & 18.5 & 89. 079 & $\mathrm{C}_{4} \mathrm{H}_{5} \mathrm{D}_{3} \mathrm{NO}$ & Ac-Gly-CO \\
\hline 211. 141 & 7.9 & 211. 141 & $\mathrm{C}_{11} \mathrm{H}_{13} \mathrm{D}_{3} \mathrm{~N}_{2} \mathrm{O}_{2}$ & -Pip-Dhb- \\
\hline
\end{tabular}

* With the exception of Pro and Pip, all residues were considered as $\mathrm{N}$-deuteriomethylated. Dab is understood as acetylated.

** From C-methylation of Gly.

$$
\text { Gly-Dab-Val-Pro-(Dab, Pip) }
$$


Considerable new light was shed on the structure of the core-hexapeptide by elemental analysis and titration data. The analytical values fitted the formula $\mathrm{C}_{26} \mathrm{H}_{46} \mathrm{~N}_{8} \mathrm{O}_{7} \cdot 2 \mathrm{CH}_{3} \mathrm{COOH} \cdot 1.5 \mathrm{H}_{2} \mathrm{O}$ or rather, as it will be shown below, $\mathrm{C}_{26} \mathrm{H}_{44} \mathrm{~N}_{8} \mathrm{O}_{6}$. $2 \mathrm{CH}_{3} \mathrm{COOH} \cdot 2.5 \mathrm{H}_{2} \mathrm{O}$. The two moles of acetic acid could be titrated with alkali (neut. equiv. 369). Titration with perchloric acid gave a neut. equiv. of 364, thus revealing two rather than three basic centers. Also, the high mobility of the corepeptide on paper chromatograms and thin-layer chromatograms was quite remarkable.

The conflict between these observations and the expected properties of a peptide with sequence I could be reconciled by assuming structure II for the core-peptide :

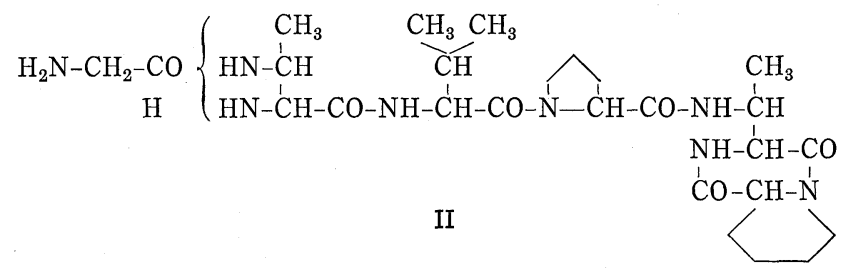

The presence of the DKP partial structure in II would diminish the number of free, ionizable groups in I from 4 to 2 and would correspondingly result in higher mobility on paper chromatograms. Furthermore, in structure II, indeed only two basic centers are available for titration with perchloric acid, while in a straight chain structure with sequence I, three basic groups should be present. Finally, structure II can fully explain the absence of the G-terminal methyl esters from the HRMS and also the presence, both among the products of pyrolysis and in the mass spectra, of the DKP LPip-Dhb- (III), the formation of which from II by elimination is not unexpected*.

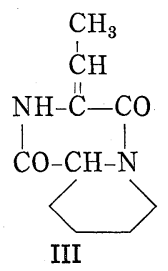

To test the absence of a free carboxyl group, the compound was subjected to electrophoresis on paper at $\mathrm{pH} 10$. The core-peptide migrated toward the cathode. This crucial experiment strongly supports structure II.

From the diketopiperazine arrangement in II, it follows directly that the prolyl residue is attached to the $\beta$ - rather than $\alpha$-amino group of the $\mathrm{D}$-threo- $\alpha, \beta$-diaminobutyryl residue. Treatment of the core-hexapeptide with nitrous acid led to the destruction of the glycine and $\mathrm{D}$-erythro- $\alpha, \beta$-diaminobutyric acid residues with the concomitant appearance of threonine. This finding would suggest that the glycine is

* Partial acid hydrolysis $\left(1 \mathrm{~N} \mathrm{HCl}, 100^{\circ} \mathrm{C}, 4\right.$ hours) of the hexapeptide yielded a ninhydrin-positive fragment, Rf 0.54, which on complete hydrolysis gave equimolar amounts of Pip and ${ }^{t} \mathrm{Dab}$. The mobility in the butanol-acetic acid-pyridine-water system indicates the DKP -Pip- ${ }^{\mathrm{t} D a b}-$. Furthermore, the HRMS of the hydrolysate, after acetylation and methylation (with diazomethane), revealed mass 194.109, corresponding to the DKP $-\mathrm{Pip-Dhb-}$ (calcd. for $\mathrm{C}_{10} \mathrm{H}_{14} \mathrm{~N}_{2} \mathrm{O}_{2}:$ 194.106), as one of the intense peaks. 
linked to the $\alpha$-amino group of ${ }^{\mathrm{D}} \mathrm{Dab}$, but the rather low yield of threonine (cf. experimental part) renders the evidence from the deamination experiment questionable. It is expected that this remaining ambiguity will be removed when the sequence study is extended beyond the hexapeptide fragment.

It should be emphasized that the diketopiperazine in II is not necessarily a genuine feature of the antibiotic. It is quite conceivable that the ring closure occurs during the long hydrolysis with weak acid, conditions applied for the removal of the aspartyl and methylaspartyl residues from the molecule of amphomycin. If this is the Ecase, then the DKP part of the core-hexapeptide could originate either from partial structure IV or from V. We hope that our present studies will clarify this question.

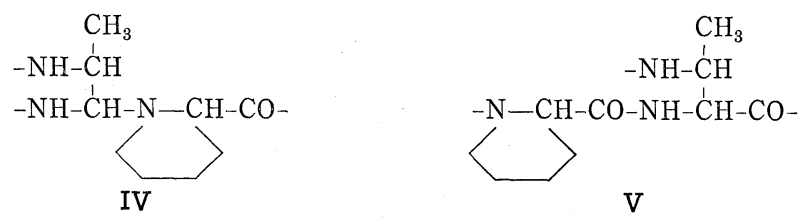

\section{Experimental}

For paper chromatography, Whatman No. $3 \mathrm{MM}$ papar and the solvent system nbutanol - acetic acid - pyridine - water (30:6:20:24) were used (descending).

For quantitative amino acid analysis, samples were hydrolyzed with constant boiling hydrochloric acid in evacuated, sealed ampoules, at $110^{\circ} \mathrm{C}$ for 16 hours. After removal of the acid by evaporation, the analyses were carried out with the aid of a Beckman-Spinco $120 \mathrm{C}$ amino acid analyzer.

Partial acid hydrolysis of amphomycin and separation of the products: (a) Purified ${ }^{3)}$ amphomycin (amphoter, $500 \mathrm{mg}$ ) was dissolved in $0.03 \mathrm{~N} \mathrm{HCl}(100 \mathrm{ml})$ and heated under reflux for 34 hours. After extraction with ether $(2 \times 100 \mathrm{ml})$, the solution was evaporated to dryness in vacuo at room temperature. The residue was dissolved in a small volume of water and applied to a column $(1 \times 10 \mathrm{~cm})$ of Dowex $1 \times 8$ in acetate cycle. The neutral and basic products were eluted with water. The acidic materials were recovered from the column with $2 \mathrm{~N}$ acetic acid and were identified as aspartic acid and $\beta$-methylaspartic acid. After evaporation to dryness of the fractions containing the neutral and basic products, the residue was dissolved in a small amount of water and applied to a column $(1 \times 10 \mathrm{~cm})$ of Dowex $50 \mathrm{~W}-\mathrm{X} 12$ in $\mathrm{NH}_{4}^{+}$cycle. The neutral material was eluted with water and was shown to be glycine. The column was then eluted with $1 \% \mathrm{NH}_{4} \mathrm{OH}$; fractions of $3 \mathrm{ml}$ were collected and were examined by thin-layer chromatography in the system $n$-butanolacetic acid-water $(3: 1: 1)$ and by paper electrophoresis at $\mathrm{pH} 3.5$ and $6.5(30 \mathrm{volts} / \mathrm{cm})$. Fractions no. $12 \sim 32$ contained a homogeneous product by these criteria. This compound $(82 \mathrm{mg})$ was found to have the following amino acid composition: Pro, 1.02; Gly, 0.97 ; Val, 0.92 ; Pip, 1.07 ; Dab, about 2.

(b) Amphomycin amphoter $(6 \mathrm{mg})$ was hydrolyzed with $0.03 \mathrm{~N}$ hydrochloric acid $(3 \mathrm{ml})$ in two evacuated, sealed ampoules at $110^{\circ} \mathrm{C}$ for 16 hours. After evaporation of the acid with a stream of nitrogen, the residue was applied on a full sheet of Whatman $3 \mathrm{MM}$ paper and chromatographed (descending) in the solvent system $n$-butanol-acetic acidpyridine-water $(30: 6: 24: 20)$. After locating the core-peptide on guide strips with ninhydrin, the corresponding band ( $\mathrm{Rf} 0.43$ ) was eluted with $30 \%$ acetic acid. The solvent was evaporated with a stream of nitrogen. Quantitative amino acid analysis gave the following ratios: Pro, 1.0; Gly, 1.0; Val, 0.75; Pip, 0.9; Dab, 1.7 (The Dab-Val bond is not completely hydrolyzed in the usual 16 -hour hydrolysis ${ }^{11}$.

(c) The neutral and basic products (obtained from $1.5 \mathrm{~g}$ amphomycin, as described 
under a) were dissolved in $c a .10 \mathrm{ml}$ of the lower layer of the solvent system, $n$-l,utanolacetic acid-pyridine-water $(4: 1: 3: 7)$ and the solution was placed into the first four tubes of a 520-tnbe automatic CRAIG apparatus (3- $\mathrm{ml}$ phases). After 520 transfers, the single withdrawal technique was followed. After 1,000 transfers, no more upper layer was added, but the distribution was continued until all tubes were free from upper phase. The core-hexapeptide was located with the help of paper chromatograms and was collected from tubes No. 231 270. The contents of these tubes were pooled, the solvents were removed by evaporation with a stream of nitrogen, and the residue was dried in vacuo at room temperature $(0.3 \mathrm{~g})$.

For analysis, a sample was dried at $45^{\circ} \mathrm{C}$ and $0.05 \mathrm{~mm}$ for 2 hours. Paper chromatograms indicated no change in the material due to the conditions of drying.

Anal. Calcd for $\mathrm{C}_{26} \mathrm{H}_{44} \mathrm{~N}_{8} \mathrm{O}_{6} \cdot 2 \mathrm{CH}_{3} \mathrm{COOH} \cdot 2.5 \mathrm{H}_{2} \mathrm{O}$ (m.w. 724.85 ): C 49.37, H 7.87, N 15.35. Neut. equiv. (assuming two basic and two acidic centers): 365 . Found : C 49.26, H 7.46, $\mathrm{N}$ 15.47. Neut. equiv. 364 (titrated with $\mathrm{HClO}_{4}$ ) : 369 (with $\mathrm{NaOH}$ ).

In the IR spectrum, no ester or lactone $\mathrm{CO}$ bands were observed. The UV spectrum shows only end absorption.

On paper chromatograms, the hexapeptide traveled with an $\mathrm{Rf}$ value of 0.43 , while a synthetic hexapeptide with the amino acid composition (Scr, Pro, Gly, Ala, Lys, Arg) had an Rf of 0.05 . On precoated silica gel thin-layer plates (Merck), in the system $n$-butanolacetic acid-water $(4: 1: 1)$, the synthetic peptide remained at the origin, while the corehexapeptide moved with an $\mathrm{Rf}$ value of 0.15 . Both on paper and on silica gel, the corepeptide gave a greenish-yellow color with ninhydrin. The color gradually turned into dark greyish purple.

Electrophoresis was carried out on the flat plate of a Savant high-voltage electrophoresis apparatus. In pyridine-acetic acid-water $(25: 1: 225)$ at $\mathrm{pH} 6.5,2,000 \mathrm{v}, 1$ hour, the peptide traveled $5.2 \mathrm{~cm}$ toward the cathode (The above-mentioned synthetic peptide traveled the same distance, lysin $6.8 \mathrm{~cm}$, leucine remained at the origin, aspartic acid moved $8.4 \mathrm{~cm}$ towards the anode). In $2 \mathrm{~N}$ acetic acid at $2,200 \mathrm{v}$ and 1.5 hours, the core-hexapeptide traveled $16.3 \mathrm{~cm}$ towards the cathode: the control-synthetic hexapeptide moved $16.2 \mathrm{~cm}$ (arginine $19 \mathrm{~cm}$ ). In $0.05 \mathrm{M}$ borate buffer, adjusted with $2 \mathrm{~N} \mathrm{NaOH}$ to $\mathrm{pH} 10$ at 3,000 $\mathrm{v}$ and 45 minutes, the core-peptide moved $2 \mathrm{~cm}$ toward the cathode, while the Dab sample used for comparison moved $1.8 \mathrm{~cm}$ toward the anode.

Determination of the $\mathrm{N}$-terminal residue of the hexapeptide by dansylation (6): A sample $(1 \mathrm{mg})$ of the hexapeptide was dissolved in $0.25 \% \mathrm{NaHCO}_{3}(0.3 \mathrm{ml})$, and a $2.5 \%$ solution $(0.3 \mathrm{ml})$ of dansylchloride in acetone was added. After 30 minutes at room temperature, the solvents were removed with a stream of nitrogen, the residue was dissolved in $6 \mathrm{~N} \mathrm{HCl}$ and hydrolyzed in an evacuated and sealed ampoule at $110^{\circ} \mathrm{C}$ for 4 hours. After removal of the hydrochloric acid, the residue was chromatographed on thin-layer plates of silica gel in a system of chloroform-benzyl alcohol-acetic acid $(30: 10: 1)$. Through comparisons with authentic samples of dansylamino acids, the $\mathrm{N}$-terminal residue of the hexapeptide could be identified as glycine.

Determination of the $\mathrm{N}$-terminal residue of the hexapeptide by Edman degradation (7): To a sample $(12 \mathrm{mg})$ of the hexapeptide dissolved in $50 \%$ aqueous pyridine $(0.2 \mathrm{ml})$, a $20 \%$ solution $(0.1 \mathrm{ml})$ of phenylisothiocyanate in pyridine was added. After 4 hours at $50^{\circ} \mathrm{C}$ (under nitrogen), the solution was evaporated to dryness and the residue dissolved in anhydrous trifluoroacetic acid. After 4 hours at $50^{\circ} \mathrm{C}$ (under nitrogen), the trifluoroacetic acid was removed in vacuo and the residue was treated with $0.03 \mathrm{~N} \mathrm{HCl}(2 \mathrm{ml})$ at $50^{\circ} \mathrm{C}$ for 15 minutes. The mixture was extracted with $n$-butylacetate $(3 \times 1 \mathrm{ml})$ and the aqueous layer evaporated to dryness. A sample of this material was hydrolyzed for quantitative amino acid analysis, as described for the hexapeptide, and was found to contain the constituents of the hexapeptide but in the following ratios: Pro, 1.00; Gly, 0.28; Val, 0.85 ; Pip, about 1 ; ${ }^{\mathrm{t} D a b}, 1.15$; ${ }^{\mathrm{e}} \mathrm{Dab}, 0.78$. 
The butyl acetate extracts were evaporated to dryness and the residue compared on thin-layer plates of silica gel, with chloroform as solvent, with authentic samples of phenylthiohydantoins derived from amino acids. Spots were revealed with an iodine azide starch reagent ${ }^{16}$. In this way, glycine was identified as the $\mathrm{N}$-terminal residue of the hexapeptide. The identity of the phenylthiodantoin was confirmed by exposure to $\mathrm{NH}_{3}$ vapors $^{16)}$ : a red color developed.

Pyrolysis: Samples of about $10 \mathrm{mg}$ were placed in a small test tube $(6 \times 25 \mathrm{~mm})$ and placed into a sublimation tube $(10 \times 250 \mathrm{~mm})$. The latter was evacuated to about $0.03 \mathrm{~mm}$ and heated at one end in an electric oven. The pyrolysate that formed between $200^{\circ}$ and $260^{\circ} \mathrm{C}$ was collected from the unheated part of the sublimation tube with chloroform. In HRMS of the sublimed material, the DKPs -Pro-Val- (found, 196.120; calcd. for $\mathrm{C}_{10} \mathrm{H}_{16} \mathrm{~N}_{2} \mathrm{O}_{2}, 196.121$ ), -Pip-Dhb- (found, 194.104; calcd. for $\mathrm{C}_{10} \mathrm{H}_{14} \mathrm{~N}_{2} \mathrm{O}_{2}, 194.105$ ) and -Pro-Gly- (found, 154.074 ; calcd. for $\mathrm{C}_{7} \mathrm{H}_{10} \mathrm{~N}_{2} \mathrm{O}_{2}, 154.074$ ) could be recognized. The last mentioned DKP is a product of the side-chain fragmentation of -Pro-Val-l. This was shown by the HRMS of authentic DPro-Val and also by the abundant mass 197 in spectra obtained by chemical ionization. In this method, the DKP -Pip-Dhbappeared as mass 195.

For HRMS, permethylation of the acetyl derivative was carried out according to Agarwal, Kenner and Sheppard ${ }^{12)}$ and repeated by the procedure of Benoiton and Coggins ${ }^{13)}$. In the treatment with $\mathrm{CD}_{3} \mathrm{I}$, the method of DAs, Géro, Ledererer ${ }^{14)}$ and Thomas, ITo ${ }^{15)}$ was followed. High-resolution mass spectral data on the derivatized hexapeptide samples were obtained using an A.E.I. MS-9 mass spectrometer coupled to a digital data system. The samples were introduced into the mass spectrometer via the direct insertion probe at temperatures between $200^{\circ}$ and $250^{\circ} \mathrm{C}$.

Deamination of the hexapeptide: A sample $(7 \mathrm{mg})$ of the hexapeptide in $0.1 \mathrm{~N} \mathrm{HCl}$ (1 ml) was treated with $\mathrm{N}_{2} \mathrm{O}_{3}$ until no more ninhydrin reaction could be observed. The $\mathrm{NaN}_{2} \mathrm{O}_{3}$ was generated from a $\mathrm{NaNO}_{2}$ and $6 \mathrm{~N} \mathrm{HCl}$ and was introduced into the solution with the aid of a slow stream of nitrogen. The reaction was carried out at room temperature and required about 3 hours. After evaporation to dryness, the residue was dissolved in $\mathrm{N} \mathrm{HCl}(8 \mathrm{ml})$ and evaporated on a steam bath under a stream of nitrogen. An aliquot was hydrolyzed for amino acid analyses in the usual way. Thr, 0.29 ; Pro, 1.0 ; Gly, 0.04 ; Val, 1.0; Pip, 1.0; Dab (mainly threo), 1.1.

\section{Acknowledgements}

The authors thank Dr. L. Szabo of H. Lundbeck \& Co. of Copenhagen-Valby, Denmark, for the generous sample of amphomycin. The contribution of Dr. A. Mauger (Research Foundation, Washington Hospital Center, Washington, D. C.), in the identification of some of the diketopiperazines by vaporphase chromatography, is sincerely appreciated. Microanalysis and titration of the core-peptide were carried out by Mr. J. Alicino (The Squibb Institute for Medical Research, New Brunswick, New Jersey). This study was supported by a grant from the U. S. Public Health Service (NIH A1-0751504). The mass spectral analyses were done pursuant to Contract No. 69-2226 with the National Institutes of Health, Department of Health, Education and Welfare.

\section{References}

1) Partrige, S. M. \& H. F. Davis : Preferential release of aspartic acid during hydrolysis of proteins. Nature $165: 62 \sim 63,1950$

2) Bodanszky, M.; N. C. Chaturvedi \& J. A. Scozzie: The structure of fatty acids from the antibiotic amphomycin. J. Antibiotics $22: 399 \sim 408,1969$

3) Bodanszky, M.; N. C. Chaturvedi, J. A. Scozzie, R. K. Griffith \& A. Bodanszky : Constituents of amphomycin. Antimicr. Agents \& Chemoth.-1969: 135 138, 1970

4) Bodanszky, M. \& G. G. Marconi : Configuration of the $\beta$-methylaspartic acid residue in amphomycin. J. Antibiotics $23: 238 \sim 241,1970$ 
5) Bodanszky, A. \& M. Bodanszky : Two diastereoisomeric $\alpha, \beta$-diaminobutyric acids from amphomycin. J. Antibiotics $23: 149 \sim 154,1970$

6) Fujıno, M. : On glumamycin, a new antibiotic. VI. An approach to the amino acid sequence. Bull. Chem. Soc. Jap. 38 : 517 522, 1965

7) Fujino, M.; M. Inoue, J. Ueyayagi \& A. Miyake : On glumamycin, a new antibiotic. V. The steric configuration of $\alpha, \beta$-diaminobutyric acid. Bull. Chem. Soc. Jap. $38: 515 \sim 517,1965$

8) Strong, C. R.; A. A. Bodanszky \& M. Bodanszky : Studies on the amino acid sequence of amphomycin. Antimicr. Agents \& Chemoth.-1970, in press, 1971

9) Hartuey, B. S. \& V. Massey : The active centre of chymotrypsin. I. Labeling with a fluorescent dye. Biochim. Biophys. Acta $21: 58 \sim 70,1956$

10) Schröder, W. A. : Degradation of peptides by the Edman method with direct identification of the PTH-amino acids. Methods in Enzymology, Vol. XI, C. H. W. Hirs, Ed. pp. 445 461, Academic Press, New York, 1967

11) Strong, R. C.; A. A. Bodanszky \& M. Bodanszky : On the "minor basic amino acid residues" of amphomycin. J. Antibiotics $23: 257 \sim 258,1970$

12) Agarwal, K. L.; G. W. Kenner \& R. C. Sheppard : Feline gastrin. An example of peptide sequence analysis by mass spectrometry. J. Am. Chem. Soc. 91 : 3096 3097, 1969

13) Benoiton, N. L. \& J. R. Coggins : Methylation as a route to peptide intermediates of N-methylamino acids and $\varepsilon-\mathrm{N}$-methyllysines. Proc. 2nd American Peptide Symposium, Cleveland, Aug. 17 19, 1970. Gordon and Breach, Science Publishers, Inc., New York, in press.

14) Das, B. C.; S. D. Géro \& E. Lederer : Detection and location of N-methyl-amino-acid residues in $\mathrm{N}$-acyloligopeptide methyl esters by mass spectrometry. Nature $217: 547 \sim 548,1968$

15) Thомаs, D. W. \& T. Iто: The revised structure of the peptide antibiotic esperin, established by mass spectrometry. Tetrahedron $25: 1985 \sim 1990,1969$

16) Pataki, G. : Dünnschichtkromatographie in der Aminosäure und Peptid-Chemie. p. 187, Walter de Gruyter \& Co., Berlin, 1966 